\title{
粉体一高分子系の非線形粘弾性
}

\author{
梅 屋

\section{Nonlinear Visco-Elastic Properties of Powder-Polymer Systems}

薰*·大 坪 泰 文*

\author{
Kaoru UMEyA* and Yasufumi Otsubo*
}

\begin{abstract}
The time-dependent nonlinear visco-elastic and the visco-plasto-elastic properties of powder-polymer solution systems were studied. That is, the steady flow and dynamic visco-elastic properties of the disperse systems containing glass beads or aerosil powder in polystyrene solutions were investigated using a coaxial cylindrical viscometer and were analyzed using an analogue simulator designed by the authors laboratory.

The remarkable rheopectic hardening properties were obtained, which indicate noticeable increase of the apparent viscosity with shearing time. And the Casson's equation could be applied to the equilibrium flow response.

The second plateau defined by Onogi et al., was also observed in the complex shear modulus vs. frequency relation at the lower side of the rubbery plateau. In this case, the noticeable distortion of a Lissajous' figure from an ellipsoid to parallelogram was observed, indicating a shifting nature from visco-elastic to plastic response.

Two kinds of nonlinearity in the stress vs. strain relation were found; one was decided from a strain amplitude dependency and the other was determined as a distortion from ellipsoid.
\end{abstract}

\section{要 旨}

粉体一高分子溶液系における時間依存性をるつ非線形 粘弾性挙動と粘塑弾性挙動について検討した。ガラスビ ーズまたはエーロジルを分散させたポリスチレン溶液の 定常流動特性と動的粘弾性挙動を二重円筒型回転粘度計 により測定し，これについて筆者らの研究室で開発した アナログシミュレーターを用いて解析した。

せん断時間により見かけ粘度が増大する顕著なレオぺ

昭和 50.9.16 受理

* 東北大学工学部応用化学科

仙台市荒巻字青葉

Faculty of Engineering, Tohoku University

Aramaki, Sendai, Japan
クシー硬化が観測された。そして，このときの平衡流動 応答に対して Casson の式が適用できた。

複素弾性率の周波数依存性曲線において，ゴム状平た ん部より低い領域で，小野木らによって定義された第二 平たん部が観測された。このとき，リサジュー図形はだ 円から平行四辺形にひずんで, 粘弾性的応答から塑性的 応答になる。

応力一ひずみの関係において，2 種類の非線形性が認 められた。1つはひずみの大きさから決定されるもので あり，他方はだ円からのひずみとして決定される非線形 性である。

\section{1. 緒言}

固体高分子や高分子液体に粉体粒子を混入すると，そ 


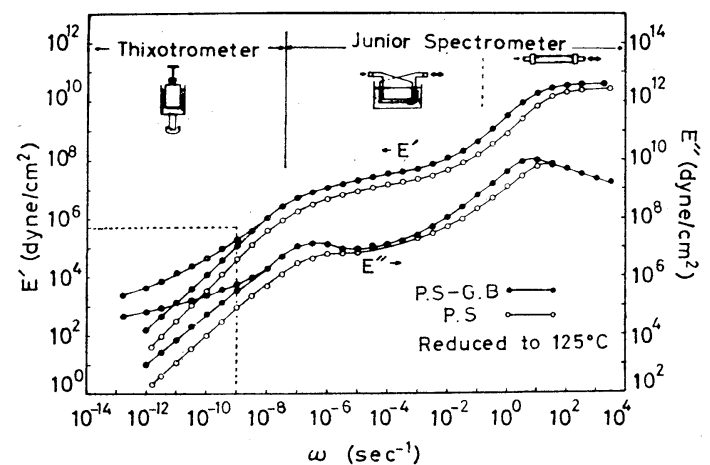

Fig. 1. Dynamic visco-elastic behavior of polystyrene and glass beads-polystyrene system

のレオロジー的性質が改善されることが知られている。 たと壳ば工業的実例として，粉体一固体高分子系におい ては FRP やカーボンブラックを充てんしたゴム，また 粉体一高分子溶液系では塗料や印刷インキなどをあげる ことができる。筆者らは, 粉体一高分子系の広いタイム スケールにわたってのレオロジー的性質について検討す るため, ガラスビーズーポリスチレン系の動的粘弾性測 定を行ない，図-1 に示す結果を得た。これは 3 つの測 定方法によって得た結果を， $125^{\circ} \mathrm{C}$ を基準温度にとって つなぎ合わせたるのである。高分子の動的粘弾性に及ぼ す粉体の効果として, 弾性率の増大, 転移領域の低周波 数側への移動があげられるが, 大きな特徵として高分子 が流動を示す低周波数に括いて，弾性率が平たんにな り, 高分子の粘弾性挙動とは著しく異なった応答を示し ていることがあげられる。松本らは，これを第二平たん 部と呼び, 分散粒子の 3 次元網目構造によるサスペンジ ョン特有の緩和機構が存在するためであると報告してい $る^{1 \sim 3)}$ 。また筆者らの実験によると，この領域でサスペ ンジョンの粘弾性挙動は, 著しい時間依存性と非線形性 を示すことが確かめられだ)。

本報告では, ガラスビーズ一ポリスチレン溶液系サス ペンジョンの第二平たん部に扣ける時間依存性と非線形 挙動, 特に塑性降伏について, 振動実験と定常せん断実 験の結果とを比較しながら考察する。

\section{2. 実験}

実験に用いた試料は; ポリスチレン $\left(\mathrm{M}_{\mathrm{W}}=28 \times 10^{4}\right)$ の $20 \%$ フタル酸ジェチル（DEP）溶液に，ガラスビー ズまたはエーロジルを分散させた系である。市販のガラ スビーズ（東芝ガラスビーズ特殊精密加工用）を，10 以下に粉碎し, 酸表面処理して用いた。

測定装置としては, 二重円筒型回転粘度計（岩本製作 所製チクソトロメータ）を用いた。測定温度範囲は 20 $\sim 80^{\circ} \mathrm{C}$ ，振動実験の角周波数範 团は $\omega=0.00105 \sim 1.05$ $\mathrm{sec}^{-1}$, せん断速度範囲は $\dot{\gamma}=0.00605 \sim 242 \mathrm{sec}^{-1}$ であ る。振動実験の場合, 特に低周波数で非線形性を示すの で, 貯蔵弾性率 $G^{\prime}$, 損失弾性率 $\mathrm{G}^{\prime \prime}$ を求めることはで きなかった。そこで, 得られたりサジュ一図形から, 複 素弾性率の絶対值 $|G *|$ (振動により生ずる応力の最大 値をその振動ひずみの最大值で割った值）を計算し，こ の値を用いて考察する。

\section{3. 結果および考察}

\section{1 時間依存性}

\section{1 .1 定常せん断実験}

図-2 は, ポリスチレンの $20 \%$ フタル酸ジエチル溶液

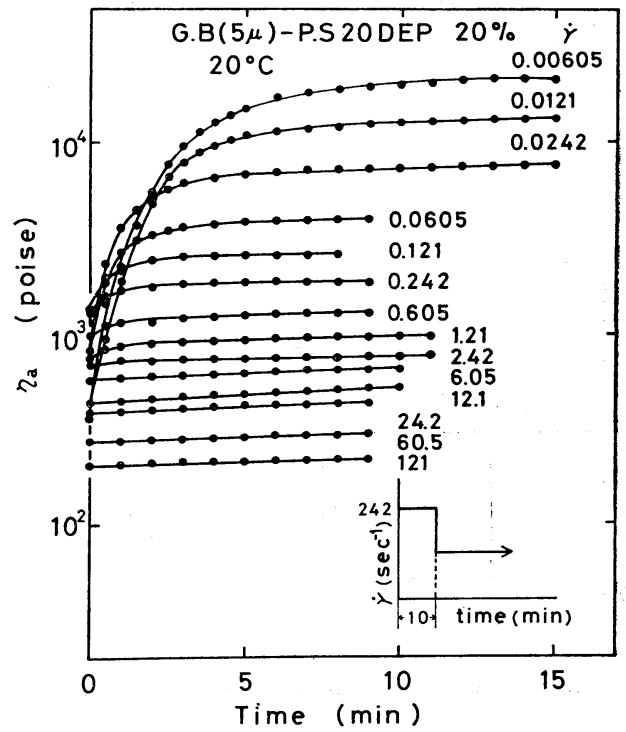

Fig. 2. Time-dependent behavior of apparent viscosity at various shear rates

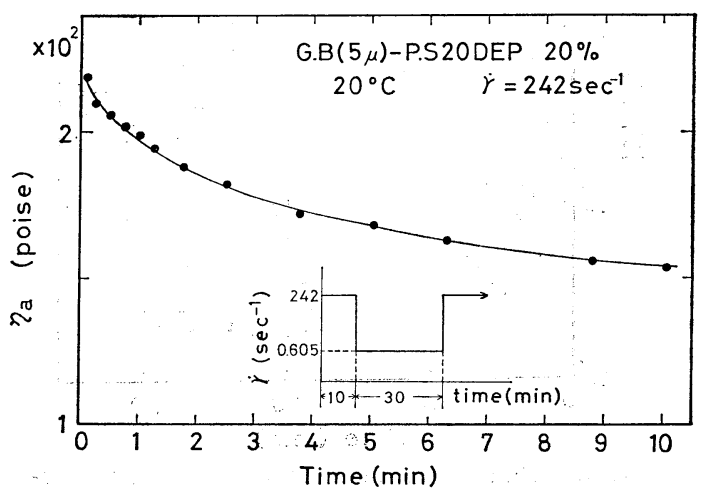

Fig. 3. Time-dependent behavior of apparent viscosity after rheopectic hardening 
(PS 20 DEP) に $20 \mathrm{wt} \%$ のガラスビーズを分散させた 系について， $\dot{\gamma}=242 \mathrm{sec}^{-1}(200 \mathrm{rpm})$ で 10 分間定常せ ん断を与えた後, 種々のせん断速度を与えたときの見か け粘度 $\eta_{a}$ の時間変化である。高せん断速度では，ほと んど見かけ粘度の時間依存性は現われないが，低せん断 速度になると時間依存性が大きくなり，時間とともに見 かけ粘度が増大するレオペクシー挙動が観測された。ま たこれとは逆に，低せん断速度で見かけ粘度が増大した 系に $\dot{\gamma}=242 \mathrm{sec}^{-1}$ の定常せん断を与えると，見かけ粘 度が減少するチクソトロピー挙動が観測された。これを 図-3 に示す。

図-2 の定常せん断実験に拈ける $t=0$ のときの流動曲 線と, 見かけ粘度が平衡值に達したときの流動曲線 $(t=$ ○）とを図-4 に示す。 $t=0$ のプロットにはばらつきが あるが，ほぼ $45^{\circ}$ の直線で近似できる。これから，10 分間 $\dot{\gamma}=242 \mathrm{sec}^{-1}$ の定常せん断を与えた系は, ニュー

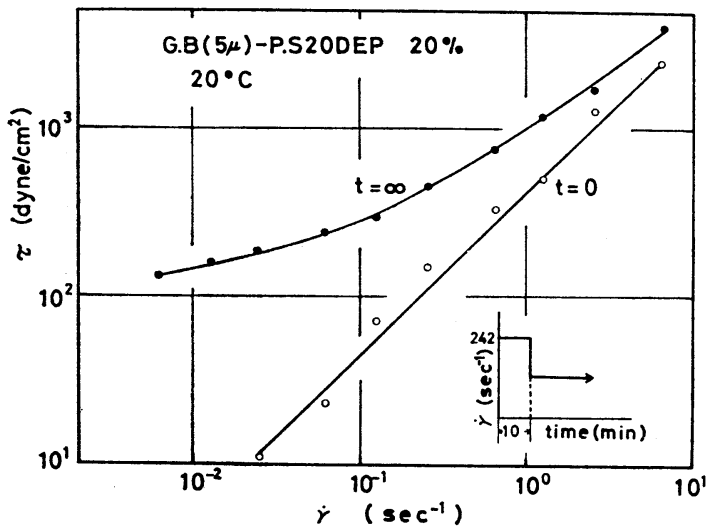

Fig. 4. Flow curves for $t=0$ and $t=\infty$ in Fig. 2

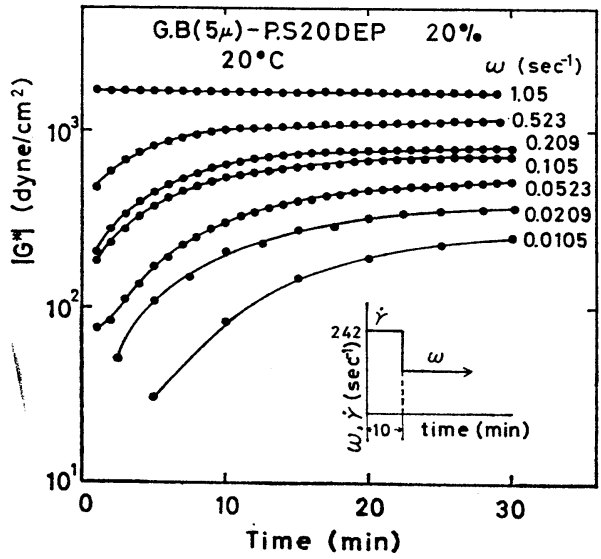

Fig. 5. Time-dependent behavior of the absolute value of complex shear modulus at various frequencies
トン流動を示すことがわかる。これに対して，見かけ粘 度が平衡值に達したとさの流動曲線は, シュードプラス チックからビンガム降伏を示す挙動となっており，レオ ペクシー回復した構造が降伏值をもつような曲線となっ ている。激しいせん断で破壊し，ゆるやかなせん断で回 復する 2 種類の構造が対応しているものと考えられる。

\section{1 .2 振動実験}

次に,レオペクシーにおける構造回復を振動実験によ って測定した結果を図-5に示す。図-2 と同じ試料に $\dot{\gamma}=242 \mathrm{sec}^{-1}$ で 10 分間定常せん断を与えた後, 種々の 角周波数で振動を与えたときの複素弾性率の絶対值 $\left|G^{*}\right|$ の時間依存性を示した。図-2 における見かけ粘度と同 様, ここでも $\left|G^{*}\right|$ が増大する結果が得られ, 角周波数 が小さい汪ど時間依存性が大きいことがわかった。つま り，ここで考えられる構造回復は，比較的ゆるやかな刺 激であるならば，定常せん断でも振動せん断でも同じよ らに起こりらると考えられる。

ところで, 刺激の大きさによる $|G *|$ の時間依存性の 違いを検討するために，角周波数を変える方法とひずみ の大きさを変える方法が考えられる。そこで，ひずみの 大きさ（二重円筒型回転粘度計における外筒振幅）を変 えて, $|G *|$ の時間依存性について調べた結果を図-6に 示す。試料および初期条件は図-5 と同じ,ひずみの大き さだけを変えてある。なお，角周波数は $\omega=0.0523 \mathrm{sec}^{-1}$ である。これも図-2, 図-5 と同様ひずみが小さいほど 時間依存性が大きいことがわかる。また， $|G *|$ が平衡值 に達したときの值がひずみにより異なるのは，拈もに系 の非線形性によるものと考えられ，これについては次節 で検討する。

以上，レオペクシーに拈ける見かけ粘度 $\eta_{a}$ と $|G *|$ の 時間依存性について検討したが， $\dot{\gamma}=242 \sec ^{-1}$ の定常せ

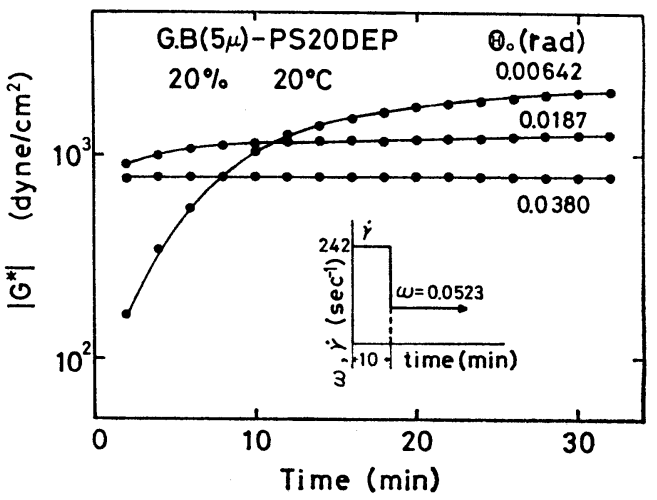

Fig. 6. Time-dependent behavior of the absolute value of complex shear modulus at various strain amplitudes 
ん断を与えた後, 定常せん断でも振動せん断でも構造回 復することがわかった。このとき，刺激が小さいほど時 間依存性が大きく, 構造回復がゆっくり起こることが観 測できた。

\section{1 .3 定常せん断実験と振動実験の比較}

次に，定常せん断実験で得られた見かけ粘度 $\eta_{a}$ と振 動実験から得られた複素粘性率 $\eta^{*}\left(=\eta^{\prime}+i \eta^{\prime \prime}\right)$ につい て考察する。いずれも粘性的性質を表わするのである が, 刺激の形式が異なるため, 得られる結果も一致しな いのが一般的である。しかし，これに対して両者の性質 を関係づけうとする多くの試みがなされている。

Cox と Merz は，見かけ粘度 $\eta_{a}$ と複素粘性率の絶対 值 $\left|\eta^{*}\right|$ が， $\omega=\dot{\gamma}$ としたとき一致するという事実学経験 的に見いだしだ5。すなわち，

$$
\begin{aligned}
\eta_{a} & =\eta^{\prime}\left[1+\left(\eta^{\prime \prime} / \eta^{\prime}\right)^{2}\right]^{1 / 2} \\
& =\left|\eta^{*}\right| \quad \text { at } \omega=\dot{\gamma}
\end{aligned}
$$

この経験則は，多くの高分子溶液および溶融物において よく成立するといらことが報告されている。ここでは， この Cox-Merz の経験則が高分子溶液を分散媒とする サスペンジョンに対しても，成立するかどらかを検討す る。

図-7 に，図-2 の $t=0$ と $t=\infty$ に括ける見かけ粘度 のせん断速度依存性, 並びに図-5の $t=0$ と $t=\infty$ にお ける複素粘性率の絶対值の周波数依存性を示す。サスペ ンジョンに $\dot{\gamma}=242 \mathrm{sec}^{-1}$ の定常せん断を与えた場合も， また振動あるいはゆるやかな定常せん断を与えてレオぺ クシー回復した後も, いずれの場合にも Cox-Merz の 経験則は成立しないことがわかった。さらに，ここで用 いたサスペンジョンについては，常に $\left|\eta^{*}\right|>\eta_{a}$ なる関 係があることがわかった。これがいかなる内容を表わし

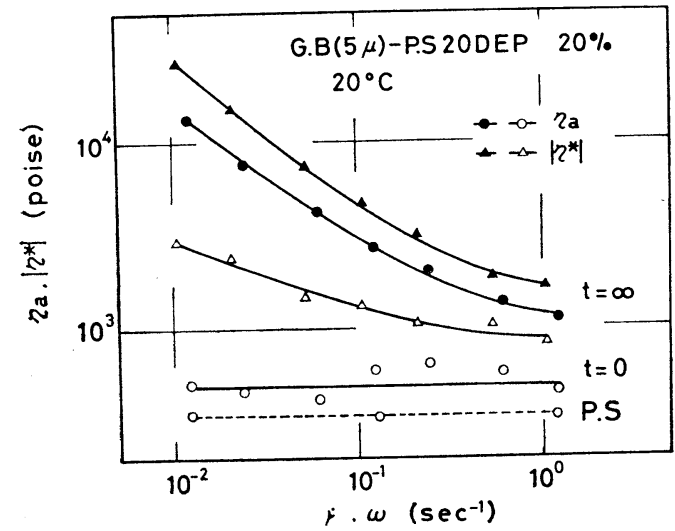

Fig. 7. Frequency dependence of the absolute value of complex viscosity and shear rate dependence of apparent viscosity
ているものであるかは明らかでないが，このような挙動 が得られたのは，粉体一高分子溶液系サスペンジョンの もつ非線形性のためであると考えられる。つまり，微小 変形に対する応答としての $|\eta *|$ とひずみ無限大に対す る応答としての $\eta_{a}$ の相違によるすのであり, サスペン ジョン特有の緩和機構の存在を表わしているものと考え られる。

\section{2 塑性降伏と非線形粘弾性}

\subsubsection{Casson の式と第二平たん部}

Casson は，せん断流動している剛体粒子の運動を記 述した Jeffery の理論6) る用いて, ニュートン流体中に 剛体球形粒子を分散させた系の流動特性を表わす式

$$
\tau^{1 / 2}=k_{0}+k_{1} \dot{\gamma}^{1 / 2}
$$

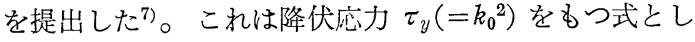
て代表的なるのである。

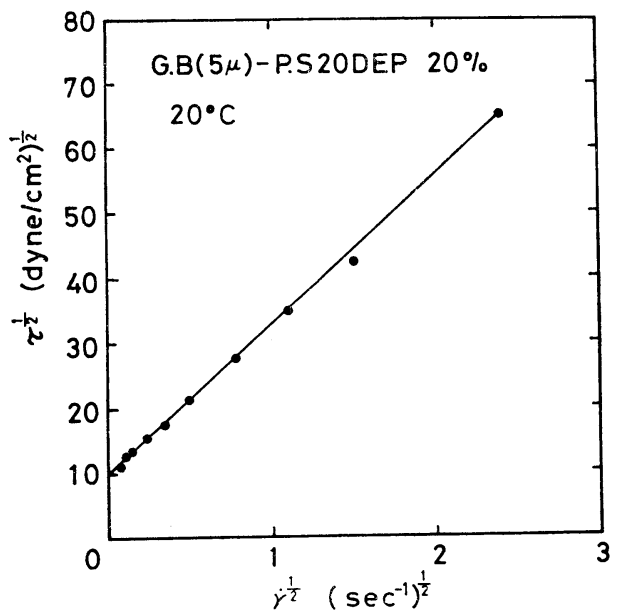

Fig. 8. Casson plots at equilibrium states

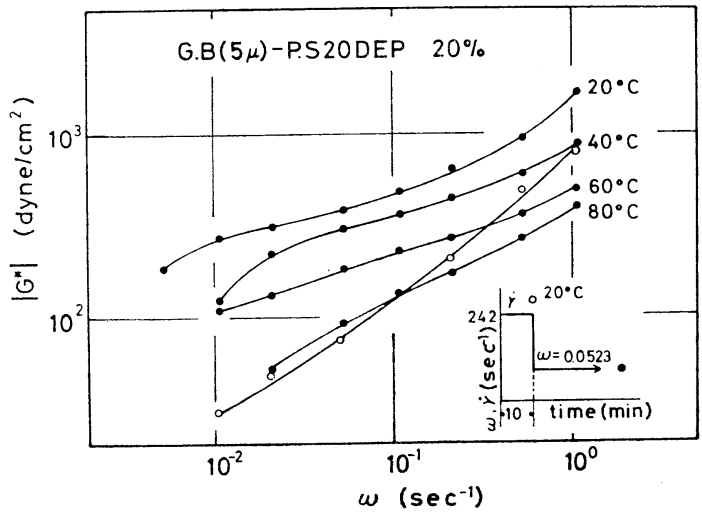

Fig. 9. Frequency dependence of the absolute value of complex shear modulus at various temperature 
さて図-4に括いて，見かけ粘度が平衡值に達したと きの流動曲線は，ビンガム降伏をするかのような挙動を 示している。そこで, この Casson の式を図-4の $t=\infty$ の結果に適して, 降伏值を求めてみた。この結果を図-8 に示す。 $\tau^{1 / 2}$ と $\dot{r}^{1 / 2}$ の間に直線関係が得られ，降伏応 力として $100 \mathrm{dyne} / \mathrm{cm}^{2}$ の值が得られた。

次に, 定常せん断実験から得られた塑性降伏と振動実 験に和ける第二平たん部との関係について述べる。

図-9には，図-5において $|G *|$ が平衡值に達した場合 に相当する振動実験の結果を示す。 $20^{\circ} \mathrm{C}$ で 10 分間 $\dot{\gamma}=$ $242 \mathrm{sec}^{-1}$ の定常せん断を与えた後の振動実験の結果を 白丸で， $\omega=0.0523 \mathrm{sec}^{-1}$ の振動を与えて $|G *|$ が平衡值 に達してから角周波数を変えて測定した結果を黒丸で示 す。なお， $\omega=0.0523 \mathrm{sec}^{-1} て ゙|G *|$ が平衡値に達してか ら，温度を変えて測定した結果も示してある。さて，こ こで白丸は図-4に护る白丸，すなわちニュートン流 動と対応して扣り，レオペクシーによる構造回復が起こ る前は，第二平たん部が現われないことを示している。 これに対して, 系がレオペクシーにより硬化した後の定 常せん断実験と振動実験の結果を比べると，前者では Casson の式にのり，後者では第二平たん部が観測され ていることがわかる。これから，定常せん断実験に打い て Casson の式によく合らということ，つまり降伏值を もった粘度式によく合らということと，振動実験におい て第二平たん部が現われるということとの間に関連があ るのではないかと考えられる。

一般に無定形の固体高分子や高分子溶液の粘弾性曲線 に対して, 時間一温度換算則が適用できる。しかし, 図 -9 に括ける $\left|G^{*}\right|$ の温度依存性より, 粉体一高分子溶液 系サスペンジョンに対しては, 時間一温度換算則が適用 できないことがわかった。これは，系が高分子溶液とは 異なった温度依存性をもつといらことであり，第二平た ん部を示すサスペンジョン特有の緩和機構が存在するこ とを表わしていると考兄られる。

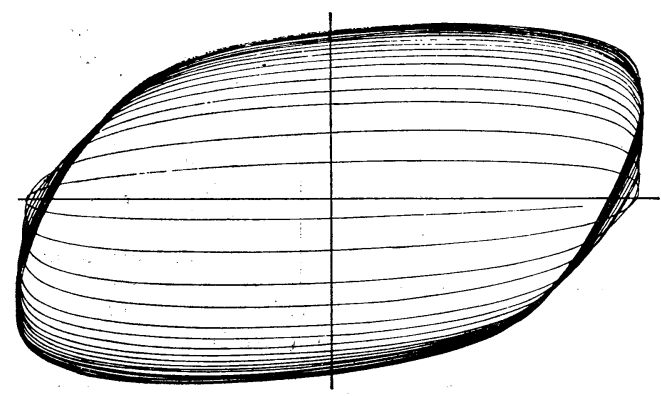

Fig. 10. Lissajous'. figure at $\omega=0.0523 \mathrm{sec}^{-1}$ in Fig. 5
3.2 .2 リサジュー困形の電気回路シミュレーション 線形粘弾性体の振動実験では, ひずみ対応力で描いた リサジュー図形がだ円になり，これから貯蔵弾性率 $G^{\prime}$, 損失弾性率 $G^{\prime \prime}$ が計算できるわけであるが, 非線形粘弾 性体の場合はだ円からひずんでくる。次に，このリサジ ニー図形のだ円からのひずみと塑性降伏について考察す る。

振動実験に括いて第二平たん部をもつ系は著しい非線 形性を示し，リサジュ一図形がだ円から平行四辺形に近 づき，応答が塑性的になる。ここで用いた系のリサジュ 一図形を図-10に示す。これは, 図-5の $\omega=0.0523 \mathrm{sec}^{-1}$ に相当するものであり, $\left|G^{*}\right|$ が増大し構造回復が進さに つれて，だ円がひずんでいくのがわかる。完全な塑性体 の場合, リサジュー図形は長方形で表わされるから，応 答はしだいに塑性的になっていると言える。

次に, このリサジュー図形を電気回路シミュレーショ. ンにより描くことを試みた。

物体の力学的性質を定量的に表わすには, その系の運 動を記述する微分方程式を解けばよいのであるが，多く の粘弾性体に打いては非線形性を示すので, 数学的取り 扱いが困難になる。これを解析する方法としては, 非線 形微分方程式をディジタル計算機で解く方法と, アナロ グ法である電気回路シミュレーションによる方法があ る。後者の方法は, 力学モデルであるバネとダッシュポ ットが電気モデルのコンデンサや抵抗と対応しているこ とに基ついて拉り, このようなモデルによる解析は, 直 感的は握が容易で, かつ装置的にも簡単であるという特 徵がある。ここでは, 非線形要素である降伏值Yを含ん だ 4 要素粘塑弾性モデルを用いることにする。

塑性降伏とは, 一定の臨界応力 $\mathrm{Y}$ 以下では変形が生じ ないが，応力が臨界值を越えると変形し，それ以降では 応力は変形速度には無関係で, 一定である挙動をいう。 降伏挙動の電気系への対応は, ある電圧まで電流は流れ ないが，臨界電圧を越えると電流が流れる挙動となる。 このような性質をもつ電気素子として定電圧ダイオード がある。実験は動的に行ならあのであるから, 降伏值と

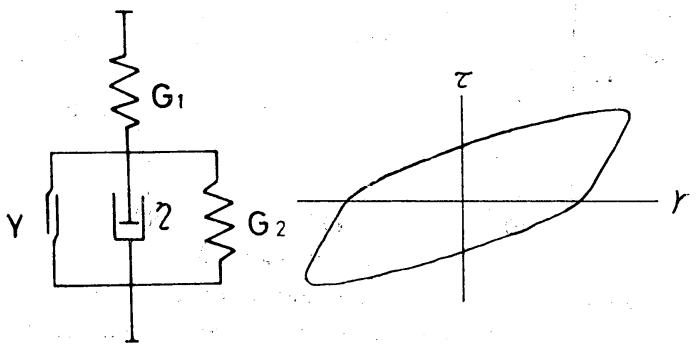

Fig. 11. Mechanical model and Lissajous' figure 
して定電圧ダイオードを2つ使用し，両方向に対する降 伏值を設定して，4 要素粘塑弾性モデルをつくった。こ のモデルにより描いたりサジュー図形の一例を図-11 に 示す。ガラスビーズーポリスチレン溶液系サスペンジョ ンで得られたりサジュー図形と似た図形が，降伏值Yを 含んだ 4 要素粘塑弾性モデルにより描かれることがわか る。

以上の結果から，ポリスチレンの $20 \%$ DEP 溶液に $20 \mathrm{wt} \%$ のガラスビーズを分散させた糸については，定 常せん断における降伏值をもった Cassonの式の適用, 振動実験に括ける第二平たん部とりサジュー図形のだ円 からのひずみ，そして電気回路シミュレーションによる 降伏值Yを含んだ 4 要素粘塑弾性モデルの適用, これら が塑性降伏という現象を通して互いに関連していること がうかがえる。

\subsection{3 非線形粘弾性}

前節まで述べてきたように, 粉体一高分子溶液系サス ペンジョンは, 特に低周波数領域で顕著な非線形性を示 す。そのため, これまでの取り扱いではすべて複素弾性 率の絶対值 $|G *|$ を用いて行なってきた。そこで, 次に だ円からひずんだリサジュー図形の解析と，ガラスビー ズーポリスチレン溶液系サスペンジョンの非線形挙動に ついて考察する。

高分子液体を分散媒とするサスペンジョンの非線形粘 弾性の解析については，松本らの報告があり，それによ ると振動波形をフーリェ解析することにより，この高調 波成分で非線形性を表現する方法を提案している8)。

今, 外筒を $\Theta=\Theta_{0} \sin \omega t$ によって正弦的に振動させ ると, 非線形粘弾性体の場合, 内筒に生ずるトルク $T(t)$ は非正弦的周期関数になるので, これをフーリェ級数に 展開し, 高次の項を無視すると

$$
\begin{aligned}
T(t) & \doteqdot A_{1} \Theta_{0}\left(G_{1}{ }^{\prime} \sin \omega t+G_{1}{ }^{\prime \prime} \cos \omega t\right) \\
& +A_{3} \Theta_{0}{ }^{3}\left(G_{3}{ }^{\prime} \sin 3 \omega t+G_{3}{ }^{\prime \prime} \cos 3 \omega t\right)
\end{aligned}
$$

と表わされる。そこで，この式の $G_{1}{ }^{\prime}, G_{1}{ }^{\prime}{ }^{\prime}, G_{3}{ }^{\prime}, G_{3}{ }^{\prime \prime}$ を非線形粘弾性関数と呼び, この值により非線形性を評 価している。しかし, この方法では $G_{3}{ }^{\prime}, G_{3}{ }^{\prime \prime}$ の物理的 意味がはっきりしないといら火点がある。筆者らはこの 点を考虑して, 非線形性の内容として今まで述べてきた ことから塑性降伏を考光に入れ，次のように解析した。

線形粘弾性体では, ひずみ対応力で描いたりサジュー 図形はだ円によるが，非線形体の場合は，これがだ円か らひずんでくる。そこで，まずりサジュ一図形の面積か らひずみと応力の位相角 角をもち、ひずみ0の点に和いて実際のリサジュ一図形 と同じ応力を示すだ円を描きこれから線形近似した動

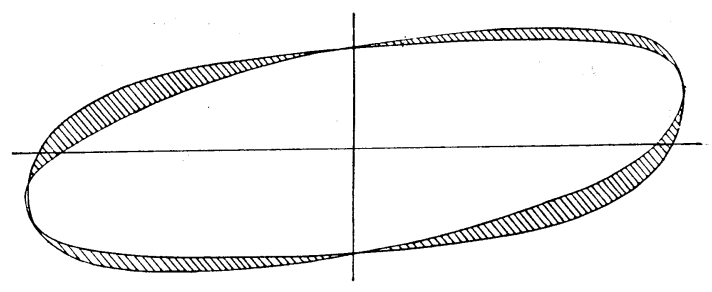

Fig. 12. Nonlinear analysis from Lissajous' figure

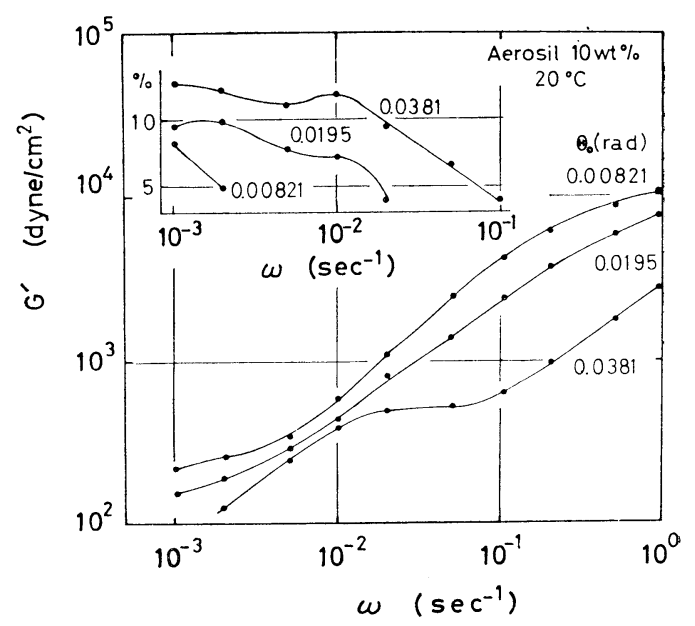

Fig. 13. Frequency dependence of $G^{\prime}$ and the rate of nonlinearity for disperse system containing $10 \mathrm{wt} \%$ aerosil in P.S solution at various strain amplitudes

的粘弾性関数 $G^{\prime}, G^{\prime \prime}$ を求める。この線形粘弾性関数 を求める際の方法は, Markovitz の方法9による。そし て, 次に図-12 に示したように, この線形近似しただ円 と実際のリサジュー図形のずれを面積で表わし，次式で 非線形性の大きさを評価して，これを非線形率と呼ぶこ とにする。

$$
\text { 非線形率 }(\%)=\frac{\text { 斜楾部分の面積 }}{\text { だ円の面積 }} \times 100
$$

このようにして，エーロジルーポリスチレン溶液系サ スペンジョンの非線形性と線形近似した場合の貯蔵弾性 率を表わしたのが図-13 である。エーロジル濃度は 10 $\mathrm{wt} \%$, 測定温度は $20^{\circ} \mathrm{C}$ ，また $\Theta_{0}$ は外筒振幅である。 これから次のことがわかった。

（1）貯蔵弾性率は周波数の高い領域でひずみ依存性 をもつがリサジュー図形はだ円に近い形状をも っている。

（2）低周波数に打いて，眝蔵弾性率のひずみ依存性 は小さくなるが，(4)式で表わされる非線形率が 大きくなり、リサジュー図形はだ円からずれてひ ずんでくる。 
（3）非線形率，すなわちりサジュー図形のだ円から のひずみは，低周波数，高ひずみ汪ど大きい。

（4）リサジュ一図形の形については，非線形率が大 きくなるにつれて，しだいに平行四辺形に近づい ていく。先ほどと同様，高ひずみ，低周波数ほど 塑性的な応答になる。

\section{4. 結論}

ガラスビーズーポリスチレン溶液系サスペンジョンの 時間依存性と非線形挙動について実験を行なった結果, 次のことが明らかになった。

（1）サスペンジョンはレオペクシー的性質をもち, 顕著な時間依存性を示すが，このとき定常せん断，振動 せん断, いずれの場合に和いても, 刺激が小さい汪ど時 間依存性が大きく，構造形成がゆっくり起こるのが観測 できる。

（2）粉体一高分子溶液系サスペンジョンに打いて は, Cox-Merz の経験則が成立しない。

（3）定常せん断実験の結果に対して，降伏値をもっ たC Cassonの式が適用できること,このとき振動実験で は第二平たん部が現われ，リサジュー困形がだ円からひ ずむことそとしてこのリサジュー図形に電気回路シミュ
レーションによる 4 要素粘塑弾性モデルが適用できるこ と, これらが塑性降伏といら現象を通して互いに関連が あると考兄られる。

（4）サスペンジョンは非線形性を示すが，ひずみ依 存性とリサジュー図形のだ円からのずれといら 2 つの非 線形性が異なる周波数領域で現われる。

\section{参考文献}

1）松本孝芳，人見千代次，小野木重治：日本レオ口 ジー学会誌, 2, 12 (1974)

2）松本孝芳，船江晴芳，小野木重治：日本レオロジ 一学会誌, 3, 91 (1975)

3) Onogi,S., T.Matsumoto, Y.Warashina: Trans. Soc. Rheology, 17, 175 (1973)

4）梅屋 薰, 磯田武信, 大坪泰文：日本レオロジー 学会誌, 3, 77 (1975)

5) Cox, W.P., E. H. Merz : J. Polym. Sci., 28, 619 (1958)

6) Sadron, C. : "Flow Properties of Disperse Systems” p. 131 (1953) North-Holland Publ., Amsterdam.

7) Casson, N. : "Rheology of Disperse Systems" (1959) Pergamon Press, London,

8) Matsumoto, T., Y. Segawa, Y. Warashina, S. Onogi : Trans. Soc. Rheology, 17, 47 (1973)

9) Markovitz, H.: J. Appl. Phys., 23, 1070 (1952) 